\title{
A Metáfora Visual no Relato Integrado: uma análise semiótica
}

The Visual Metaphor in the Integrated Report: a semiotic analysis

La Metáfora Visual en el Informe Integrado: un análisis semiótico

DOI: 10.1590/1809-5844201924

\author{
João Batista Freitas Cardoso ${ }^{1}$ \\ https://orcid.org/0000-0002-0192-3478 \\ Nadson Jaime Ferreira Alves ${ }^{2}$ \\ https://orcid.org/0000-0001-9348-841X \\ Isabel Cristina dos Santos ${ }^{3}$ \\ https://orcid.org/0000-0001-5505-5234
}

${ }_{1}^{1}$ (Universidade Municipal de São Caetano do Sul, Pró-Reitoria de Pós-Graduação, Programa de Pós-Graduação em Comunicação. São Caetano do Sul - SP, Brasil).

${ }^{2}$ (Universidade Federal do Pará, Instituto de Ciências Sociais Aplicadas, Faculdade de Ciências Contábeis. Belém - PA, Brasil).

${ }_{3}^{3}$ (Universidade Municipal de São Caetano do Sul, Pró-Reitoria de Pós-Graduação, Programa de Pós-Graduação em Administração. São Caetano do Sul - SP, Brasil).

\section{Resumo}

O Relato Integrado é uma recém-incorporada prática de comunicação corporativa, concisa e inovadora, que recorre a símbolos da linguagem visual na apresentação das informações. Dada a novidade, este artigo explora a comunicação visual nos Relatos Integrados das empresas participantes do Programa Piloto brasileiro, com foco no uso de um tipo de signo específico, a metáfora visual. Trata-se de pesquisa qualitativa, do tipo exploratório-descritiva e delineamento documental. No que se refere ao uso da metáfora visual, a pesquisa visa responder à seguinte pergunta: qual o padrão dominante da linguagem visual das informações econômico-financeiras e não financeiras nos Relatos Integrados das empresas participantes do Programa Piloto no Brasil? A análise apoia-se nos temas previstos na Estrutura Conceitual do Relato e nas categorias sígnicas de Peirce.

Palavras-chave: Relato Integrado. Metáfora. Comunicação Visual. Semiótica de Peirce. Stakeholders. 


\begin{abstract}
The Integrated Report is a new corporative communication practice, concise and innovative, which uses visual language symbols in the presentation of information. Due to its novelty, this article explores the visual communication in the Integrated Reports of companies participating in the Brazilian Pilot Program, focusing on a specific type of sign, the visual metaphor. This is a qualitative study, supported by descriptive and exploratory research, outlined by documentary data collection. Regarding visual metaphor, this research aims to answer: which is the dominant pattern of visual language applied to the corporate information, whether economic or financial or of any other kind, observed in the most concise Integrated Report developed by the companies in the Brazilian Pilot Program? The analysis of the contents is related to the Conceptual Structure of the Integrated Report according to the Peirce's Classes of Sign.
\end{abstract}

Keywords: Integrated Report. Metaphor. Visual Communication. Peirce's Semiotics. Stakeholders.

\title{
Resumen
}

El Informe Integrado es una práctica recién incorporada de comunicación corporativa, concisa e innovadora, que utiliza símbolos del lenguaje visual en la presentación de información. Dada la novedad, este artículo explora la comunicación visual en los Informes Integrados de las empresas que participan en el Programa Piloto brasileño, centrándose en el uso de un tipo específico de signo, la metáfora visual. Se trata de una investigación cualitativa, exploratoria descriptiva y de delimitación documental. Con respecto al uso de la metáfora visual, la investigación apunta a responder la siguiente pregunta: ¿cuál es el patrón dominante del lenguaje visual de la información económico-financiera y no financiera en los Informes Integrados de las empresas que participan en el Programa Piloto en Brasil? El análisis se basa en los temas proporcionados en la Estructura Conceptual del Informe y en las categorías de signos de Peirce.

Palabras clave: Informe Integrado. Metáfora. Comunicación Visual. Semiótica de Peirce. Partes Interesadas.

\section{Introdução}

O Relato Integrado (RI) deriva de um processo social evolucionário e inovador na comunicação corporativa, reflexo de mudanças na concepção e gestão empresarial, em relações dialéticas entre a empresa e stakeholders (ROCHA; GOLDSCHMIDT, 2010).

De acordo com Freeman (2010), stakeholder é qualquer indivíduo ou grupo que possa afetar os objetivos organizacionais ou que possa ser afetado pelos resultados alcançados. Ou seja, envolve desde investidores, fornecedores, colaboradores, consumidores, além dos organismos governamentais e não governamentais, potenciais colaboradores e clientes e das comunidades do entorno das empresas ou dos fornecedores. Considerando os aspectos relacionais que envolvem os stakeholders (PESQUEUX; DAMAK-AYADI, 2005), o RI deve ser compreendido como um processo de comunicação com possibilidade de atender aos diferentes agentes que financiam os vários capitais da organização, contribuindo na reflexão 
da amplitude da comunicação com usuários de variados níveis, contemplando interesses nem sempre concatenados.

O RI originou-se no “The Prince’s Accounting for Sustainability Project”, de 2004, lançado pelo Príncipe Charles, em parceria com a International Accounting Standard Board e a Global Reporting Initiative, e resultou no International Integrated Reporting Council (IIRC), entidade articuladora do RI no mundo (MACIEL; CINTRA, 2015).

O documento integra os relatórios de Sustentabilidade, Econômico-Financeiro, Administração e de Governança Corporativa que, separadamente, tinham baixa conexão (ECCLES; KRZUS, 2011). Essa integração permite evidenciar a estratégia sustentável, alinhando as ações de responsabilidade social corporativa, com foco nas necessidades das partes interessadas, reduzindo discrepâncias e inconsistências (ECLLES; KRZUS, 2011), cuja lacuna no debate esta pesquisa explora, ao qual se soma o potencial de significação da linguagem visual das informações no RI.

Desde 2012, mais de 100 organizações no mundo aderiram ao Programa Piloto - IIRC Business Network, para testar fundamentos do RI (CHENG; IOANNOU; SERAFEIM, 2014). Até 2017, 150 empresas de diferentes países o haviam adotado - incluindo o Brasil, com um dos maiores números de empresas participantes. São elas: AES Brasil, BNDES, CCR, CPFL Energia, Fibria, Itaú, BRF, Grupo Segurador Banco do Brasil e Mapfre Seguradora, Natura, Petrobrás, Via Gutenberg e Votorantim Cimentos.

Neste estudo, buscou-se responder à seguinte questão: qual o padrão dominante da linguagem visual das informações econômico-financeiras e não financeiras nos Relatos Integrados das empresas participantes do Programa Piloto no Brasil? Considerando que a metáfora visual se apresenta como um tipo de signo com estrutura complexa que tende a gerar relações de sentido inovadoras, o principal objetivo é identificar as estratégias de uso da metáfora visual nas informações do RI.

\section{Aspectos comunicacionais do Relato Integrado}

Para Eccles e Krzus (2011), faz diferença informar as metas e a visão da empresa, além do feedback às partes interessadas, propiciando uma comunicação responsável e transparente. O International Integrated Reporting Council (2013) define essa comunicação, concisa e que alinha estratégia, governança, desempenho e perspectivas de criação de valor na organização em curto, médio e longo prazo, como Relato Integrado.

O IIRC (2013) prevê a integração da visão geral da empresa e ambiente externo; modelo de negócios e governança; riscos e oportunidades; estratégias e alocação de recursos; finalizando com desempenho e perspectivas nas quais se baseiam a apresentação de resultados, explicitado em seis tipos de capital: financeiro, humano, intelectual, de relacionamento, manufaturado e natural.

Para o IIRC (2013, p. 7), “o principal objetivo de um relatório integrado é explicar a provedores de capital financeiro como uma organização gera valor ao longo do tempo [...]”. 
E ressalta que o Relato deve enfatizar a "capacidade da organização de atender aos legítimos interesses e necessidades das principais partes interessadas”, ressaltando a necessidade de uma linguagem, clara e concisa (INTERNATIONAL INTEGRATED REPORTING COUNCIL, 2013, p. 3). Ainda, destaca que o relato aumenta a transparência e a prestação de contas, essenciais para construir confiança e resiliência, exortando como legítimos os interesses e necessidades das principais partes interessadas e que eles são considerados nas decisões, ações e desempenhos (INTERNATIONAL INTEGRATED REPORTING COUNCIL, 2013), sugerindo uma prestação de conta com os financiadores dos diferentes capitais.

Eccles e Spiesshofer (2015) sugerem que os relatórios corporativos contemplem as externalidades negativas geradas pela empresa e os esforços para mitigá-las; interesses e expectativas de outras partes com as quais pode contribuir no desenvolvimento sustentável; equilíbrio adequado entre satisfazer as expectativas dos acionistas e dos demais interessados; envolvimento de investidores institucionais no desempenho sustentável e decisões de investimento; e perspectiva de longo prazo para a empresa e investidores.

A análise científica demanda conceitos subsidiários, por meio dos quais é possível compreender os problemas, formular hipóteses, escolher métodos de investigação apropriados, bem aos propósitos deste estudo que investiga o potencial de significação da linguagem visual do Relato para diferentes usuários.

Para sistematizar os fundamentos do RI, o IIRC divulgou, em dezembro de 2013, o framework resultante dos debates nos fóruns internacionais e do processo de experimentação junto às empresas do programa piloto. Por se tratar de orientações que precisam se adequar à cultura de diferentes países e empresas, o framework do RI (INTERNATIONAL INTEGRATED REPORTING COUNCIL, 2013) é baseado em princípios gerais (Quadro 1) e não em regras específicas, para garantir a flexibilidade diante das peculiaridades de cada empresa, sem perder de vista a possibilidade de comparações entre os relatos. A intenção é encontrar o equilíbrio entre flexibilidade e prescrição.

Quadro 1 - Características obrigatórias do Relato Integrado - Princípios

\begin{tabular}{ll}
\hline Orientações & Fundamentos \\
\hline $\begin{array}{l}\text { Foco estratégico e } \\
\text { orientação para o futuro }\end{array}$ & $\begin{array}{l}\text { Oferecer a visão da estratégia da organização, relação com a } \\
\text { capacidade de gerar valor em curto, médio e longo prazo, bem } \\
\text { como uso e impactos sobre os capitais. }\end{array}$ \\
\hline $\begin{array}{l}\text { Conectividade da } \\
\text { informação }\end{array}$ & $\begin{array}{l}\text { Mostrar a inter-relação e dependências entre os fatores que afetam } \\
\text { a capacidade da organização de gerar valor ao longo do tempo. }\end{array}$ \\
\hline $\begin{array}{l}\text { Relações com partes } \\
\text { interessadas }\end{array}$ & $\begin{array}{l}\text { Prover visão da natureza e da qualidade das relações da } \\
\text { organização com as principais partes interessadas, inclusive como } \\
\text { entende, como considera e como responde aos legítimos interesses } \\
\text { e necessidades destas partes. }\end{array}$ \\
\hline
\end{tabular}




\begin{tabular}{ll}
\hline Orientações & Fundamentos \\
\hline Materialidade & $\begin{array}{l}\text { Divulgar informações sobre assuntos que afetam, } \\
\text { significativamente, a capacidade da organização de gerar valor em } \\
\text { curto, médio e longo prazo (relevância). }\end{array}$ \\
\hline Concisão & $\begin{array}{l}\text { Retratar apenas o contexto suficiente para entender a estratégia, a } \\
\text { governança, o desempenho e as perspectivas da organização, sem } \\
\text { adentrar em informações menos relevantes. }\end{array}$ \\
\hline Confiabilidade e & $\begin{array}{l}\text { Abranger todos os temas materiais, positivos e negativos, em } \\
\text { equilíbrio e isento de erros significativos. }\end{array}$ \\
\hline Completude & Apresentar informações em bases coerentes no decorrer do \\
comparabilidade & tempo, permitindo comparação com outras organizações na \\
& medida em que seja relevante à capacidade de gerar valor ao \\
longo do tempo.
\end{tabular}

Fonte: INTERNATIONAL INTEGRATED REPORTING COUNCIL (2013).

Há situações em que a conciliação de todos os princípios exige bom senso ou justificativa de prioridades. Em razão disso, o framework prevê conteúdos mínimos a serem evidenciados (Quadro 2). Como o framework alerta sobre a possível dificuldade de sincronizar concisão e completude, ganha importância a síntese por meio da linguagem visual.

Quadro 2 - Características obrigatórias do Relato Integrado - Conteúdos

\begin{tabular}{ll}
\hline Orientações & Fundamentos \\
\hline $\begin{array}{l}\text { Visão geral } \\
\text { organizacional e } \\
\text { ambiente externo }\end{array}$ & $\begin{array}{l}\text { O que a organização faz e quais as circunstâncias em que ela atua. } \\
\text { Identifica a missão, a visão da organização e fatores significativos que } \\
\text { afetam o ambiente externo e a resposta da organização. }\end{array}$ \\
\hline Governança & $\begin{array}{l}\text { Como a estrutura de governança apoia a capacidade de gerar valor em } \\
\text { curto, médio e longo prazo: estrutura de liderança, processos usados em } \\
\text { decisões estratégicas, monitoramento da gestão estratégica e de riscos, } \\
\text { cultura, ética e valores da organização. }\end{array}$ \\
\hline Modelo de negócios & $\begin{array}{l}\text { Sistema de transformação de insumos em produtos, por meio das } \\
\text { atividades da empresa, bem como os impactos relacionados ao } \\
\text { cumprimento dos propósitos estratégicos da organização ao gerar valor } \\
\text { em curto, médio e longo prazo. }\end{array}$ \\
\hline Riscos e oportunidades & $\begin{array}{l}\text { Riscos e oportunidades específicos que afetam a capacidade de a } \\
\text { organização gerar valor em curto, médio e longo prazo, e como lida } \\
\text { com eles. }\end{array}$ \\
\hline $\begin{array}{l}\text { Estratégia e alocação } \\
\text { de recursos }\end{array}$ & $\begin{array}{l}\text { Onde a organização deseja ir e como pretende chegar: objetivos, } \\
\text { estratégias, plano de alocação de recursos e indicadores de desempenho. }\end{array}$ \\
\hline
\end{tabular}




\begin{tabular}{ll}
\hline Orientações & Fundamentos \\
\hline Desempenho & $\begin{array}{l}\text { Nível em que a organização se encontra em relação aos objetivos } \\
\text { estratégicos para o período. Indicadores quantitativos sobre metas, } \\
\text { riscos e oportunidades. Efeitos positivos e negativos da organização } \\
\text { sobre os capitais, ao longo da cadeia de valor. O estado dos } \\
\text { relacionamentos com as principais partes interessadas. Vínculos entre o } \\
\text { desempenho passado, atual e futuro. }\end{array}$ \\
\hline Perspectiva & $\begin{array}{l}\text { Desafios e incertezas que a organização tende a enfrentar para } \\
\text { implantar sua estratégia e potenciais implicações para o Modelo de }\end{array}$ \\
& Negócios e desempenho futuro da empresa. \\
\hline Base para preparação e e & Como a organização determina os temas incluídos no RI e como são \\
apresentação & quantificados e/ou avaliados. \\
\hline
\end{tabular}

Fonte: INTERNATIONAL INTEGRATED REPORTING COUNCIL (2013).

Assim, o RI deve ser entendido como o meio pelo qual se comunica aos stakeholders o pensamento integrado da empresa. Nesse sentido, sua formulação exige entendimento profundo e articulado do processo de criação de valor da empresa. Para o IIRC (2013, p. 19), “um Relato Integrado deve divulgar informações sobre assuntos que afetam de maneira significativa, a capacidade de uma organização de gerar valor em curto, médio e longo prazo”. E prossegue, o processo para determinar materialidade para fins de preparação e apresentação do RI envolve: (i) a identificação de temas relevantes; (ii) a avaliação de temas relevantes quanto ao efeito conhecido ou potencial sobre a geração de valor; (iii) a priorização de temas com base na sua importância em relação aos demais; e (iv) a determinação de informações a serem divulgadas sobre temas relevantes.

Tais implicações podem ser diretas à organização ou indiretas, quando podem afetar capitais pertencentes ou disponíveis a outros (INTERNATIONAL INTEGRATED REPORTING COUNCIL, 2013). Esse é um dos diferenciais da evidenciação no Relato Integrado em relação ao relatório financeiro.

Para o International Accounting Standards Board - IASB, a informação é material e a materialidade é baseada na natureza ou na magnitude - ou em ambas - dos itens a qual a informação está relacionada, no contexto do relatório contábil-financeiro da entidade em particular (CFC, 2011). Para a Global Reporting Initiative - GRI (2013), a materialidade deve abordar aspectos com impactos econômicos, ambientais e sociais significativos da organização; ou que influenciem, de forma substancial, as avaliações e decisões de stakeholders. É o limiar a partir do qual os aspectos tornam-se suficientemente expressivos para serem relatados, por afetar a capacidade da organização em satisfazer necessidades presentes, sem comprometer as necessidades de gerações futuras. 


\section{A semiótica de Peirce e a Metáfora Visual}

Devido à sua capacidade para servir como instrumento teórico-analítico, que permite compreender o potencial de significação de objetos concretos (por meio de signos verbais, visuais, sonoros e suas combinações), as teorias semióticas têm sido adotadas por diferentes áreas do conhecimento - como na Administração e na Contabilidade, áreas em que se desenvolvem os estudos sobre os usos de RI no processo de comunicação das organizações. Neste texto, ao fazer uso da teoria semiótica de Charles Sanders Peirce, considera-se o RI sob seu aspecto comunicacional.

Peirce (2003) considerava o signo, em todas as suas formas e manifestações, como algo que permite representar um objeto e gerar significações. Em Peirce, o signo é o veículo que leva algo do exterior para a mente; o representado é o objeto; o comunicado é a significação; e a ideia que provoca é o interpretante, podendo ser uma palavra, um livro, um grito, uma pintura, uma pessoa, uma fotografia, um sinal de trânsito, qualquer objeto que signifique algo para alguém (SANTAELLA, 2002).

A lógica de Peirce (2003) é fundamentada em três categorias universais: primeiridade, secundidade e terceiridade. A primeiridade é o potencial do signo, percebido pelas qualidades imediatas: cores, formas, cheiros, sons, sabores, texturas que despertam sentimentos incertos, possibilidades livres de certezas. Tão fugaz que precede a síntese e se oculta imediatamente no pensamento. Resulta do primeiro contato e se expressa no frescor das sensações inenarráveis, sem julgamento do raciocínio.

A secundidade liga o signo a algo existente (dualidade), envolve relação, dependência, ação e reação. Existência, resistência e reação para ocupar espaço e tempo no universo, no confronto com outros corpos, respostas em forma de signos, marcas perceptíveis que, em maior ou menor grau, o ser deixa como rastros de sua existência histórica, social, circunstancial e singular. Posterior ao puro sentir da primeiridade e anterior ao pensamento articulado da terceiridade.

A terceiridade aproxima a primeiridade e a secundidade numa síntese intelectual. Para compreender os fenômenos, a consciência produz o signo, que media a relação entre ele e o indivíduo. Nesse processo, os signos são convencionados e legitimados, pois representam, percebem e interpretam o mundo.

Para Peirce (2003), a terceira categoria pressupõe a segunda e a primeira. Para ser aceito signo de terceiridade, o signo deve ser convencionado aos objetos a partir das características qualitativas (signo de primeiridade). A segunda categoria pressupõe a primeira, por indicar o objeto real ("objeto dinâmico", nos termos de Peirce) a partir de suas qualidades físicas. Já a primeira é livre, por ser formada apenas pelas características qualitativas que suscitam possiblidades (NÖTH; SANTAELLA, 2014). Essas três categorias multiplicam-se em três tipos de relações. São justamente essas relações que nos permitem apontar os potenciais de significação de um dado objeto. 
A matriz de classificação em nove signos (Quali-signo, Sin-signo, Legi-signo, Ícone, Índice, Símbolo, Rema, Dicente e Argumento), organizadas nas três categorias acima descritas, é a mais detalhada da obra de Peirce (2003). A primeira tricotomia (Quali, Sin e Legi) trata de possibilidades, pois não há relação efetiva com o objeto, tampouco com o interpretante. Se o objeto é limitado por características qualitativas do signo, é um quali-signo; se sugere possibilidades de relação com um existente específico, singular, é um sin-signo; se é uma possibilidade a signo legitimado, é um legi-signo.

A relação do signo com o objeto também é apresentada em três modalidades: os ícones são signos que sugerem objetos pelas qualidades; os índices são signos que indicam objetos existentes; e os símbolos são signos que representam, legitimamente, tais objetos.

O caráter simbólico, signos de terceiridade, dá-se pelo uso de signos convencionais em forma de letras, números, representações visuais que permitem a propagação do conteúdo contido no texto e na linguagem visual, predominando o aspecto pragmático. Dessa maneira, o símbolo porta uma convenção coletiva e não individual. O caráter indicial propicia as referências, os sentidos do texto, da imagem e da semântica. O índice indica um existente específico, concreto, singular. Há, entre o signo e o objeto que ele representa, uma conexão, o que o habilita a apontar diretamente para o objeto. Já o caráter icônico, na linguagem visual, apoia a compreensão das características qualitativas da imagem. De acordo com Santaella (2002), o ícone é o tipo de signo que sugere o seu objeto: “parece ser”, “parece com”. É nesse último tipo, como se observará adiante, que reside a metáfora visual.

O nível do interpretante, Peirce (2003) também divide em três: Rema, Dicente e Argumento. 'A teoria dos interpretantes de Peirce (2003) detalha o processo, ou percurso analítico, dos três modos que capacitam qualquer coisa a funcionar como signo: o rema (qualidade de sentimento), o dicente (constatação de uma existência) e o argumento (compreensão do caráter de lei).

Os interpretantes gerados por esses signos apresentam-se em três níveis. O primeiro nível é o imediato, caracterizado pelo potencial interpretativo do signo, previamente. Dá-se pelo potencial dos signos escolhidos pelo emissor da mensagem, antes de chegar ao receptor (usuário) - esta pesquisa analisa o potencial de significação dos signos visuais que representam as empresas via Relato, independentemente da perspectiva dos usuários. O segundo nível de interpretante é o dinâmico, trata do efeito que o signo provoca no usuário, considerando a dimensão psicológica e sociológica, as influências do momento, a trajetória e as afinidades, e a experiência colateral. O terceiro nível, interpretante final, trata da interpretação ideal, o estágio máximo em que todo interpretante dinâmico deveria alcançar na busca da "interpretação verdadeira” ao explorar o potencial de significação dos signos, dada certas condições. Devido a essas premissas, este estágio é considerado quase utópico.

De acordo com Nöth (2013, p. 20), é preciso considerar que:

A teoria da interpretação peirciana não é uma teoria hermenêutica, que prescrevesse qual das leituras possíveis de certos textos seja certa e qual errada, 
nem uma teoria dogmática que proibisse leituras individuais. Conforme Peirce, interpretações são interpretantes, efeitos que um signo cria num intérprete, mas estes efeitos podem ser de muitas ordens: sentimento, emoção, afecção, admiração, ação, obsessão, agressão, repúdio, convicção, crença, guerra e paz. Só alguns deles são lógicos. A suposição de que textos só possam ter uma única interpretação não se sustenta na semiótica de Peirce.

Para a análise de linguagens visuais, Nöth e Santaella (2014) recomendam que, na análise do signo em relação com o objeto (ícone, índice e símbolo), se dê destaque aos tipos de ícones (imagem, diagrama e metáfora). Nesse texto, trataremos especificamente da metáfora como signo icônico. Para Peirce (2003, p. 64), "todo método de comunicação indireta de uma ideia deve depender, para ser estabelecido, do uso de um ícone. Daí segue-se que toda asserção deve conter um ícone ou conjunto de ícones”.

O signo icônico, ou hipoícone, de acordo com Peirce (2003), possibilita representar um objeto por comparação, em três modalidades: imagem, similaridade ao nível das qualidades (formas, cores, texturas); diagrama, similaridade das relações entre partes de um todo, como ocorre no organograma e no fluxograma; e metáforas verbal ou visual, pelo paralelo entre o caráter simbólico de um signo e algo diverso dele. De acordo com Peirce (2003, p. 64)

Os hipoícones, grosso modo, podem ser divididos de acordo com o modo de Primeiridade de que participem. Os que participam das qualidades simples, ou Primeira Primeiridade, são imagens; os que representam as relações, principalmente as diádicas, ou as que são consideradas, das partes de uma coisa através das relações análogas em suas próprias partes, são diagramas; os que representam o caráter representativo de um representâmen através da representação de um paralelismo com alguma coisa são metáforas.

As metáforas, especificamente, estão no grupo de signos em “cuja semelhança é ajudada por regras convencionais”(PEIRCE, 2003, p. 65), universo dos signos de terceiridade. Recorrendo a Pignatári, Ferraz Jr. (2011) lembra que Peirce utilizou a expressão “primeira primeiridade [...] para referir-se ao grau de similaridade imediata que apreendemos entre as imagens e seus objetos”. Daí deduz-se que: os diagramas configurariam uma "segunda primeiridade"; e as metáforas uma "terceira primeiridade, pois representam as qualidades do seu objeto por meio de uma equivalência, em determinado contexto, entre dois representâmens” (FERRAZ JR., 2011, p. 72). Para o autor, por estarem embutidas em relações triádicas, as metáforas seriam ícones argumentais - que tendem a gerar interpretante de terceiridade.

O que é, de fato, peculiar ao terceiro tipo de hipoícone é que, nele, o reconhecimento da similaridade entre representâmen e objeto (vale dizer, o 
reconhecimento da iconicidade) estará sempre condicionado à interpretação de uma equivalência semiótica, resultando assim de um processo relativamente mais abstrato do que aquele exigido por uma analogia, ou por uma réplica das qualidades simples do objeto (FERRAZ JR., 2011, p. 73).

Nesse sentido, a "representação de paralelismo” a que Peirce (2003) se refere faz da metáfora uma unidade semiótica complexa composta de diversos signos. Ferraz Jr. (2011, p. 74) explica essa relação da seguinte maneira:

A representação de um paralelismo ocorre, por exemplo, quando empregamos um signo ou representâmen (S1) num contexto em que o mais usual seria o emprego de outro signo (S2), pois estamos pressupondo que S1 e S2 são igualmente aptos a representar um determinado objeto $(\mathrm{O} 2)$. O caráter representativo de S1, isto é, a sua capacidade de substituir S2 em determinados aspectos, será então deduzido a partir de uma equivalência semiótica [...]. Qualquer que seja o modo de representação em que se definam as relações de S1 e S2 com os seus respectivos objetos não-metafóricos (O1 e O2) [...] somente pela via de uma inferência lógica relativamente complexa (mais precisamente de uma semiose do tipo argumental) é que a qualidade extraída desse paralelismo permitirá a associação metafórica entre S1 e O2.

Nesse sentido, para o autor, o ícone metafórico possui em sua estrutura complexa, mas sem se restringir a ele, um legissigno simbólico argumental. É justamente essa estrutura que visa ao interpretante argumentativo, que entendemos apresentar-se como uma forma inovadora de comunicação no âmbito do RI.

\section{A Metáfora Visual no Relato Integrado}

Este estudo analisa o potencial de significação da linguagem visual - com ênfase no uso do ícone metafórico - nos Relatos da amostra de empresas que participam do Programa Piloto, no Brasil. Utilizam-se como base os oito temas da Estrutura Conceitual do IIRC. A coleta de dados ocorreu de forma não probabilística nos Relatos de nove empresas brasileiras participantes do Plano Piloto (AES Brasil, BNDES, CCR, CPFL Energia, Fibria, Itaú, BRF, Natura e Votorantim Cimentos), referentes aos exercícios de 2014 e 2015, totalizando 18 relatos, com média de 76 páginas cada.

$\mathrm{Na}$ análise, constatou-se que 94\% das páginas recorrem a algum elemento visual no processo de comunicação (fotografia, desenho, gráfico, fundo colorido ou barra superior ou inferior acompanhada, ou não, de título ou logomarca da empresa). Se consideradas apenas as páginas com fotografia e/ou diagrama, que mais interessam a esse estudo, esse percentual alcança $73 \%$. 
Na primeira etapa de tratamento e análise dos dados, foi caracterizada a estrutura de cada Relato. Na segunda, tendo definido as páginas como unidades de contexto e tipos de linguagens como unidades de registro, foi feita a leitura e classificação das páginas por temas/ categorias (Visão geral organizacional e ambiente externo; Governança; Modelo de negócios; Riscos e oportunidades; Estratégia e alocação de recursos; Desempenho; Perspectiva; Base para preparação e apresentação) e tipos de signos, recorrendo-se ao software Nvivo 11 for Windows (2017).

No software Nvivo 11 (2017) procedeu-se ao: cadastramento dos Relatos; criação de oito nós com base nos oito temas previstos na Estrutura Conceitual do Relato, ou categorias (Quadro 2). Em cada categoria foram consideradas as relações dos signos com os objetos.

Em razão do grande número de imagens analisadas, apresentamos aqui uma amostra de cada categoria que serve como exemplo das estratégias utilizadas pelas empresas para comunicar as características obrigatórias por meio das metáforas.

\section{Base de Preparação e Apresentação}

Em sintonia com as orientações do IIRC (2013), a organização deve informar como determina, quantifica e avalia os temas do RI. São informações que servem para entender o processo de elaboração, com efeito na credibilidade do relato.

Na relação do signo com o objeto, para retratar as bases de preparação e apresentação do relato, prevalecem, por meio do uso de fotografias, os signos indiciais. Desse modo, trata-se de linguagem visual que aponta para o real, indica algo existente. Algo alinhado aos propósitos desse tema. O predomínio desse tipo de signo também pode ser observado nas demais categorias.

No que se refere ao tipo de ícone, prevalece o uso de imagens, seguido de diagramas e, em menor quantidade, a metáfora visual. Nesse sentido, o uso de fotografias é bem presente no interior dos relatos. Grande parte dessas fotografias divide o espaço com texto verbal. Trata-se de uma maneira de aperfeiçoar o espaço, em busca da concisão.

Na Figura 1 (Sumário do RI BNDES), o aspecto icônico sugere uma representação do paradigma pré-fotográfico (SANTAELLA; NÖTH, 2014), universo das produções artesanais - especificamente, por meio da semelhança (imagem), as gravuras de cordel. O diagrama se apresenta pela similaridade de relações entre os tópicos que compõem a estrutura do relato, com suas respectivas páginas. A metáfora, por sua vez, se apresenta via tema transversal, dando significado de brasilidade ao relato, por meio da estética de cordel que subjaz com as imagens.

A representação de paralelismo ocorre quando a imagem (S1) - no tratamento gráfico da ilustração e dos números das páginas - remete, por semelhança, a um interpretante, cordel (O1), enquanto a estrutura diagramática do sumário (S2) remete a outro interpretante, os tópicos que compõem a estrutura do relato do BNDES (O2). Em outros termos, isolando S1 e S2, um intérprete que não conheça o documento pode se lembrar da arte do cordel ao olhar a 
imagem e outro, que tenha familiaridade com RI, pode compreender a lógica do documento por meio da estrutura diagramática. As relações que podem ser estabelecidas entre S1 e S2, e seus respectivos objetos (O1 e O2), resultam no interpretante potencial dessa página. Ou seja, S1 remete à imagem do BNDES (O2), o Banco Nacional de Desenvolvimento Econômico e Social se apresenta como uma organização que reflete valores do país. Percebe-se, assim, a complexidade de relações semióticas que precisam ser estabelecidas pelo intérprete para que a imagem (S1) seja relacionada ao RI da organização (O2).

Figura 1 - Sumário Relato Integrado BNDES

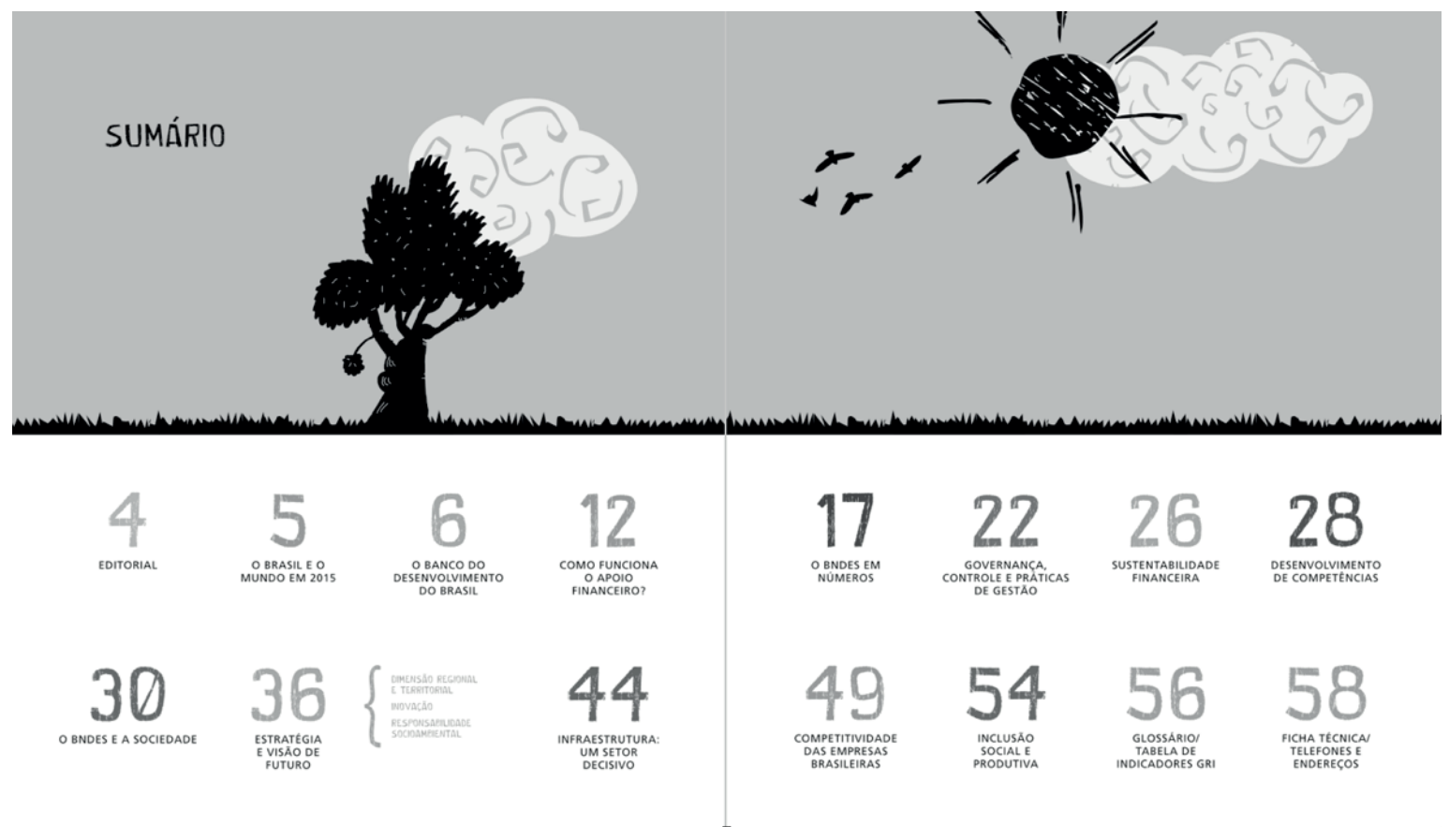

Fonte: Relato Integrado BNDES (2015, p. 2-3).

\section{Visão Geral Organizacional e Ambiente Externo}

Nesse tema deve ser informado o que a organização faz e quais as circunstâncias em que atua (INTERNATIONAL INTEGRATED REPORTING COUNCIL, 2013). Dentre as páginas classificadas neste tema, destacam-se: mensagem do conselho de administração e da diretoria executiva, contexto e cenário.

Cerca de 200 páginas foram identificadas com esse tema. Na relação do signo com objeto, a função indicial está presente nos 18 relatos analisados. Quanto ao tipo de ícone, prevalece o uso de imagens para expressar a visão geral da organização e o ambiente externo, normalmente em forma de fotografias, em 117 páginas. Outras 44 apresentam algum tipo de 
diagrama. Em 11 páginas foram identificadas metáforas visuais que reproduzem a aparência externa de objetos apenas como meio para representar algo que não está visualmente acessível, como exemplifica a Figura 2. A metáfora da teia (S1) serve para informar, de maneira sintética e concisa, sobre as relações estabelecidas entre as diferentes dimensões da organização (O2).

Figura 2 - Metáfora da teia de aranha

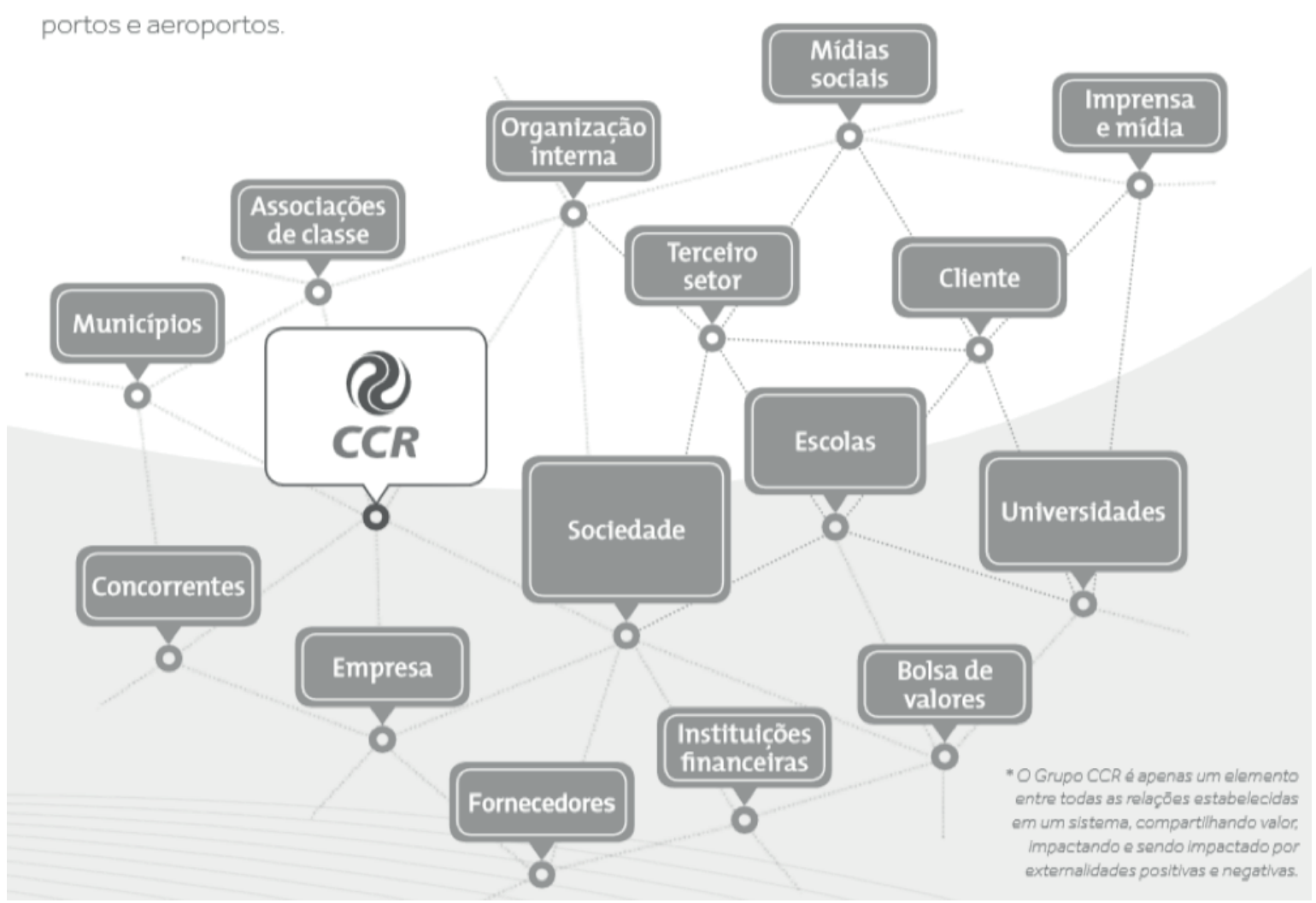

Fonte: Relato Integrado CCR (2015, p. 9).

Em se tratando de linguagem visual do RI, concisão e clareza são aspectos fundamentais na construção do interpretante imediato. Todavia, devem proporcionar segurança, tal como no texto verbal, por isso as imagens precisam ser bem dimensionadas.

\section{Governança}

Consoante a esse tema, o RI deve informar como a estrutura de governança apoia a capacidade de gerar valor em curto, médio e longo prazo (INTERNATIONAL INTEGRATED REPORTING COUNCIL, 2013). Trata-se de um dos temas mais presentes no conjunto de relatos analisados. 
Quanto ao signo icônico, foram classificadas 92 páginas nos 18 relatos que utilizam a imagem (ilustração ou fotografia); outras 18 páginas, em oito relatos, recorrem a imagem plástica (sem o uso da figuratividade).

A metáfora visual se apresenta de maneira clara na Figura 3. Nela, é sintomática a complementariedade entre linguagem visual e linguagem verbal para falar de ética e transparência. Olhos nos olhos, proximidade, confiança e satisfação são vários conceitos reforçados pela metáfora para evidenciar o modelo de governança. Desse sentimento de confiança e satisfação, abre-se caminho para expor o Modelo de Negócio.

Figura 3 - Ética e transparência em linguagem visual

\section{Ética e transparência}

Prática recorrente, Natura atualiza seus processos buscando reforçar postura e comportamento éticos

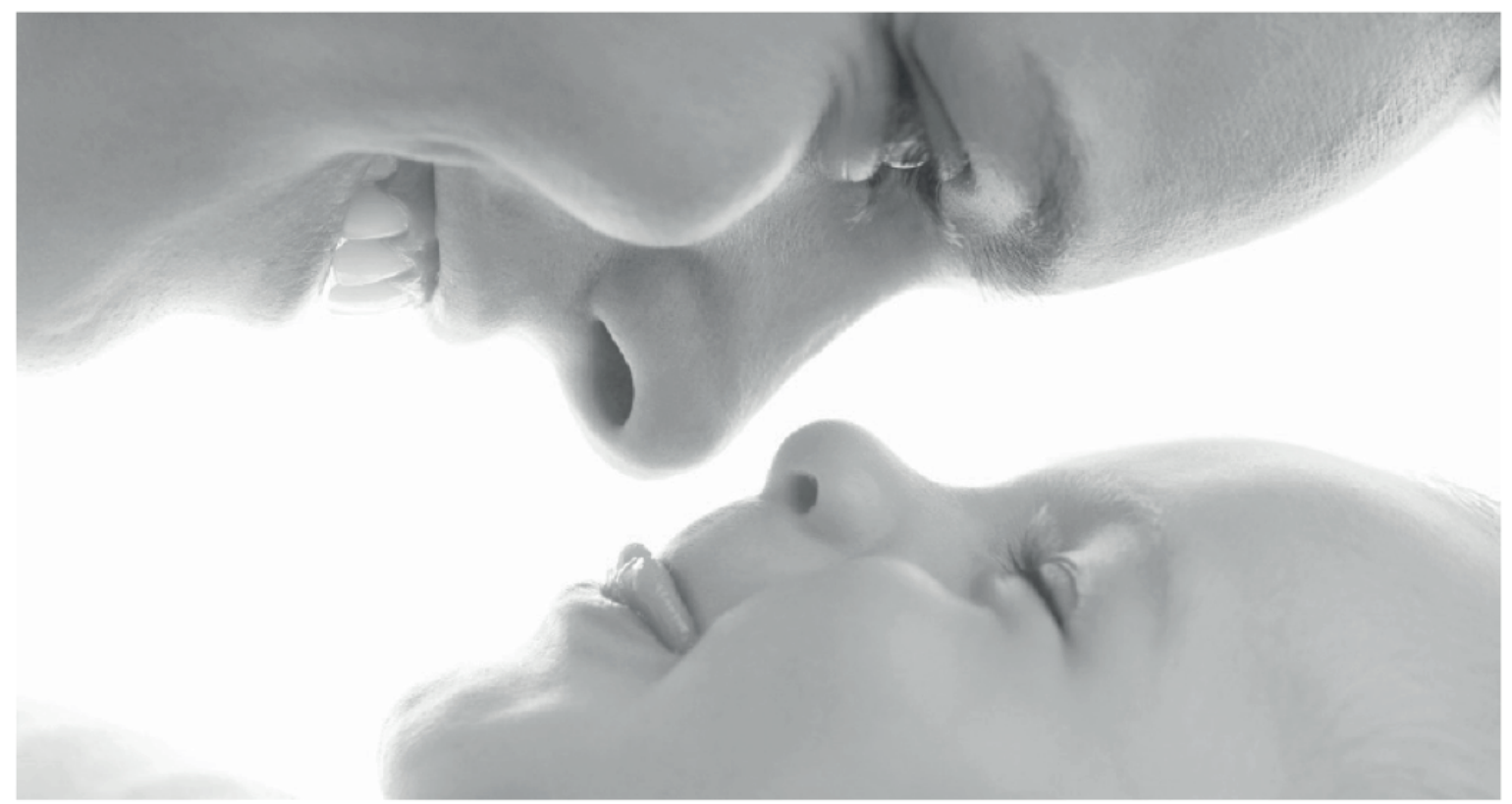

Fonte: Relato Integrado Natura (2014, p. 19).

\section{Modelo de Negócios}

O Modelo de Negócios evidencia a articulação dos capitais para se converterem em criação de valor e a maneira como podem ser medidos pelos principais indicadores de 
desempenho, bases para construção do pensamento integrado. Esse tema costuma recorrer à linguagem visual devido à variedade de conteúdos envolvidos.

Quanto ao tipo de ícone, percebe-se a supremacia de imagens e diagramas, tanto em número de páginas, quanto em número de relatos. Ainda assim, há presença de metáforas.

Na Figura 4, os desenhos que indicam os capitais são tipos de ícones em forma de imagem, representação do objeto pela similaridade nas características qualitativas: formas e cores. O processo de criação de valor forma um diagrama, composto pela entrada dos seis tipos de capitais, processamento destes por meio de atividades e produtos e a saída, evidenciada na distribuição percentual do valor criado por cada tipo de capital, inclusive a contribuição negativa do capital social e de relacionamento. As engrenagens que representam a sincronia das ações de governança são exemplo de metáfora, similaridade de ideias que faz paralelo entre o significado de um signo e algo diverso dele, com o intuito de simplificar a mensagem.

Figura 4 - Modelo de Negócio Itaú

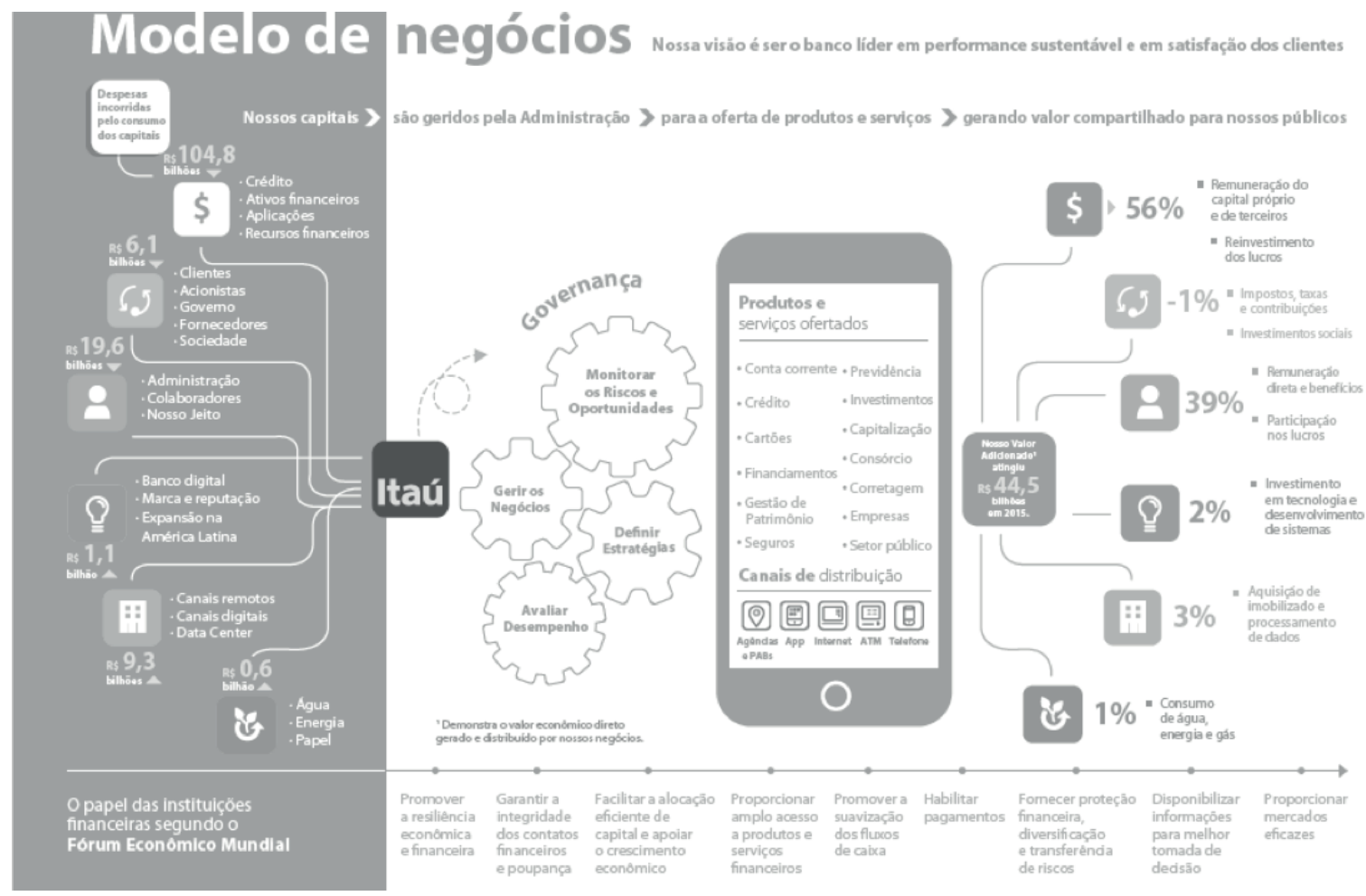

Fonte: Relato Integrado Itaú (2015, p. 8).

A Figura 5 também recorre à imagem metafórica, seja pelo conjunto que lembra literatura de cordel - já observado anteriormente -, seja pelas partes com metáforas 
específicas, como as gotas de chuva que representam os diversos tipos de capital que irrigam o solo ou a árvore frondosa que entrega à sociedade diversos produtos e serviços. Destaca-se o conteúdo que alimenta a metáfora visual: insumos que nutrem a árvore pela raiz; e aos frutos maduros que geram resultados em curto prazo e os frutos em maturação para a longo prazo.

Figura 5 - Modelo de Negócio BNDES

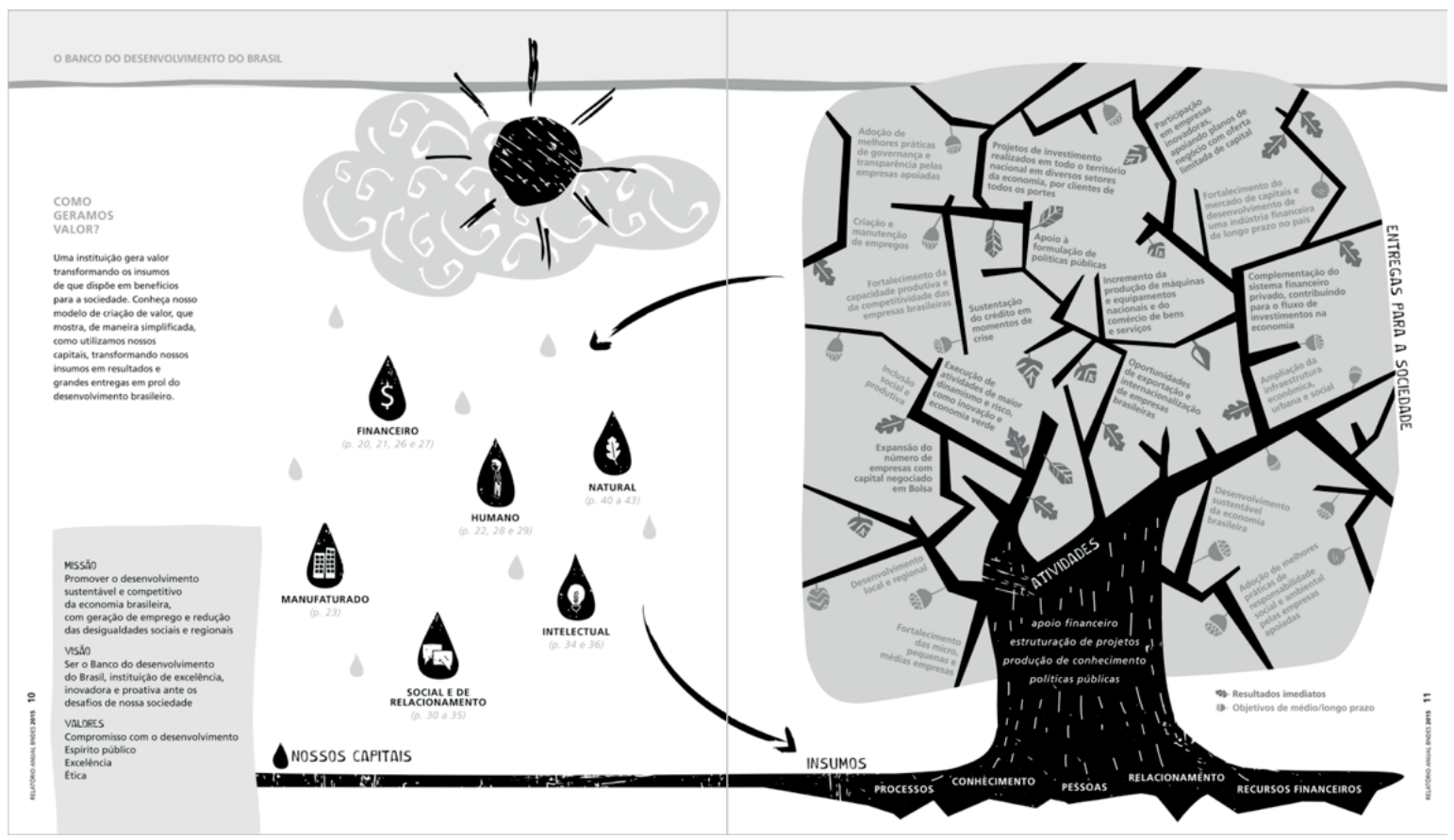

Fonte: Relato Integrado BNDES (2015, p. 10-11).

\section{Riscos e Oportunidades}

Para o IIRC (2013), o RI deve informar riscos e oportunidades que afetam a capacidade de a organização gerar valor em curto, médio e longo prazo, e como lidar com eles, pois redução do risco deve ajudar as empresas a reduzir custos e se tornar mais rentável (ROTH, 2014). No geral, são pouco expressivos os exemplos de linguagem visual para retratar esse tema. Foi identificada linguagem visual relacionada a risco em 17 relatos e cerca de 80 páginas, mas sempre a imagem contida nesse tema é específica para retratar o risco.

A Figura 6 é um dos poucos exemplos em que se pode identificar a metáfora visual neste tema, ainda que esse tipo de signo não seja preponderante. A imagem estilizada do frasco de erlenmeyer, que tende a se referir à área da Química, é utilizada aqui para 
representar como os resultados de pesquisas científicas podem colaborar com as ações de redução de riscos ambientais.

Figura 6 - Riscos ambientais

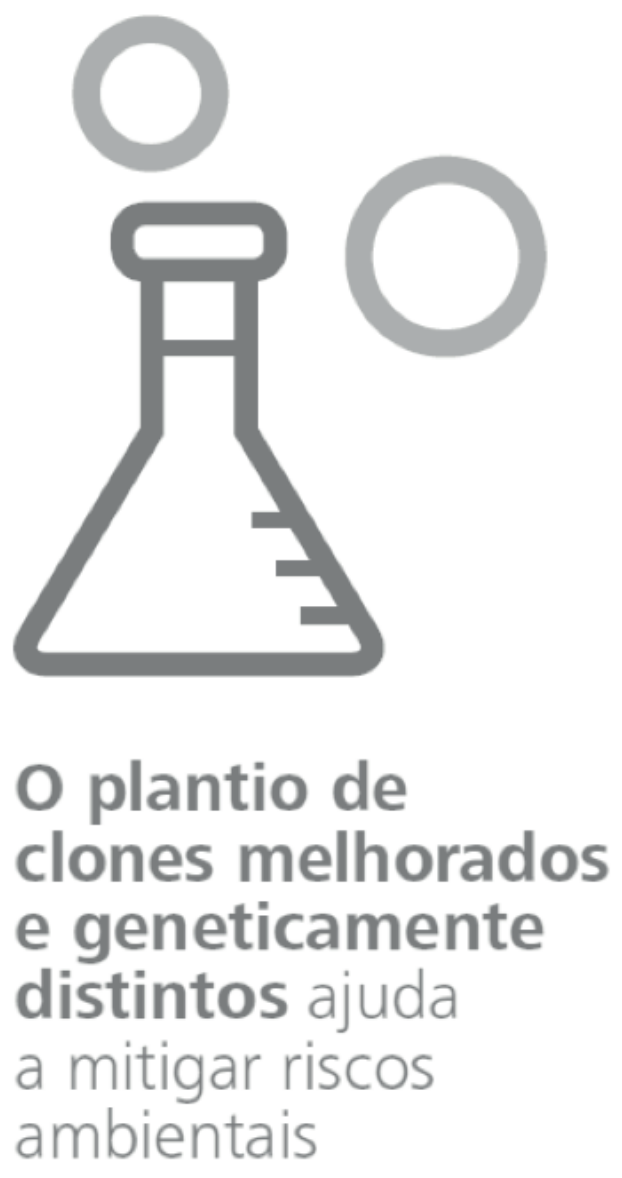

Fonte: Relato Integrado Fibria (2015, p. 45).

\section{Estratégia e Alocação de Recursos}

O RI deve informar os objetivos da empresa e a maneira de alcançá-los para gerenciar riscos e maximizar oportunidades na alocação de recursos (INTERNATIONAL INTEGRATED REPORTING COUNCIL, 2013).

O signo icônico que prevalece nesta categoria é o imagético, quase o dobro das páginas que apresentam diagramas e cinco vezes mais do que as que apresentam metáforas. Em sua maioria, essas imagens são representações fotográficas, como a Figura 7, que 
exibe mãos sobrepostas, sugerindo, pela semelhança, serem as mãos de uma criança, de uma mulher adulta e de um homem adulto. Essas mãos possuem o potencial de gerar o interpretante “família”, em que o maior (e/ou mais forte) sustenta (e/ou protege) o menor (e/ ou mais frágil). Tal imagem se apresenta como uma metáfora ao potencializar a estratégia com significado de segurança e acolhimento, sensações importantes para serem despertadas em investidores e demais stakeholders. Afinal, refere-se diretamente à segurança com o futuro da empresa.

Figura 7 - Estratégia

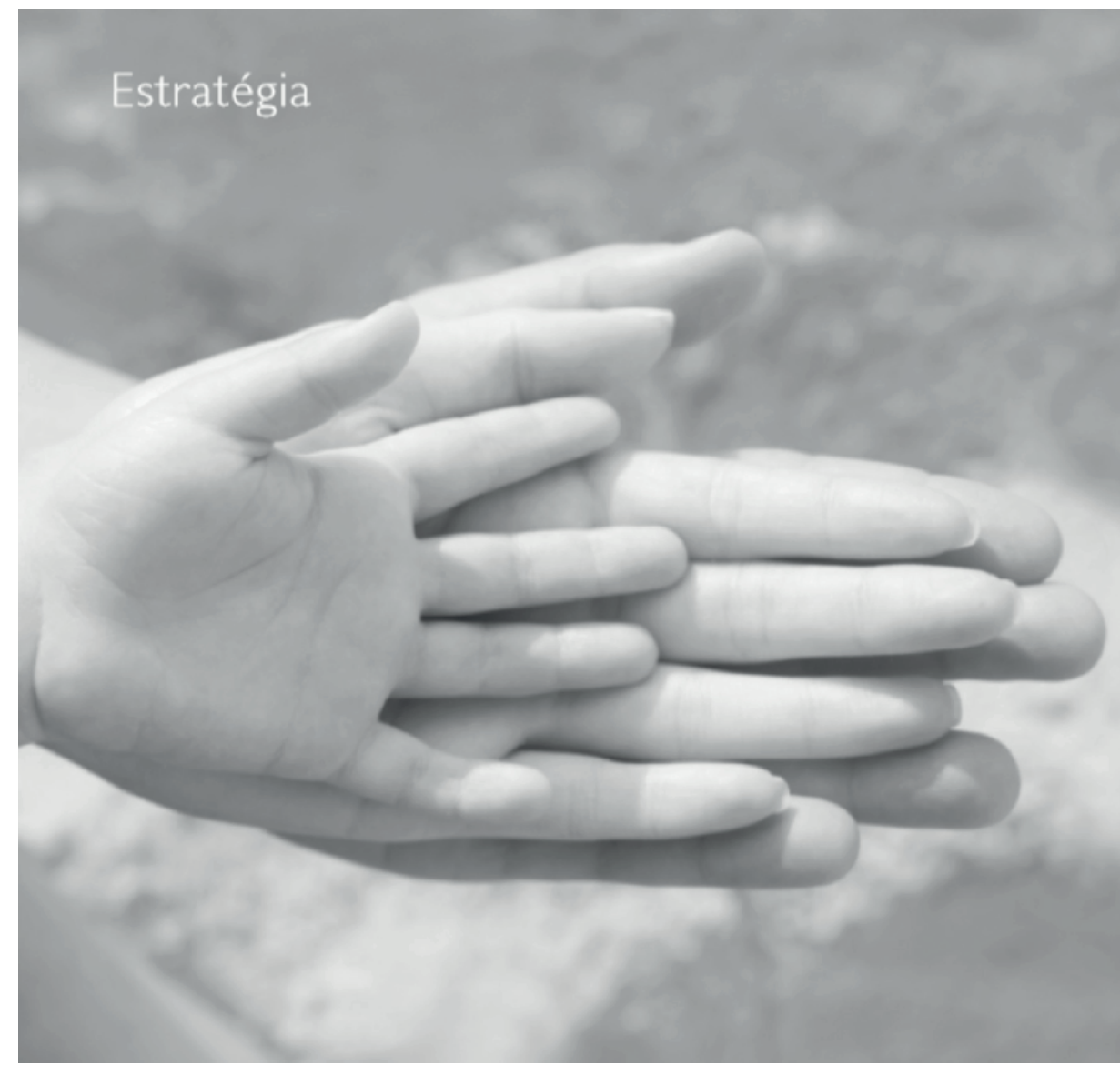

Fonte: Relato Integrado Natura (2014, p. 12).

Esse tipo de estratégia aparece também em outros relatos, como a Figura 8, em que a imagem explora a similaridade do livro aberto com o telhado de uma casa visando potencializar o significado de acolhimento, proteção. 
Figura 8 - CPFL nas Escolas

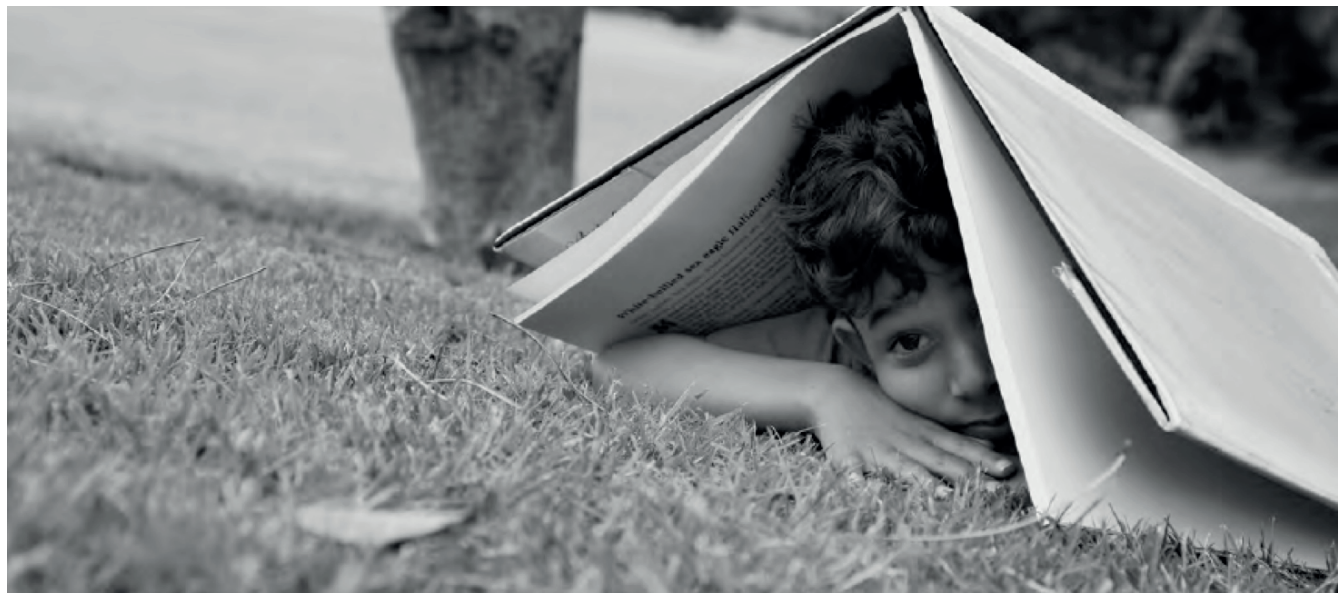

Fonte: Relato Integrado CPFL (2015, p. 64-65).

A Figura 9 é também um exemplo de metáfora, ao se aproveitar da similaridade do objeto arco e flecha para expressar as prioridades estratégicas da empresa. Tal recurso potencializa o interpretante imediato ao acentuar o significado de impulsão do ponto de partida (figuração mais fraca) ao ponto de chegada (figuração mais forte da seta), ao retratar prioridades que nascem na alma da empresa para impulsionar os resultados. São elas: cadeia sustentável, inovação, pessoas, qualidade, vendas e logísticas e a marca, todas diferenciadas por cores e símbolos.

Figura 9 - Estratégia: arco de prioridades

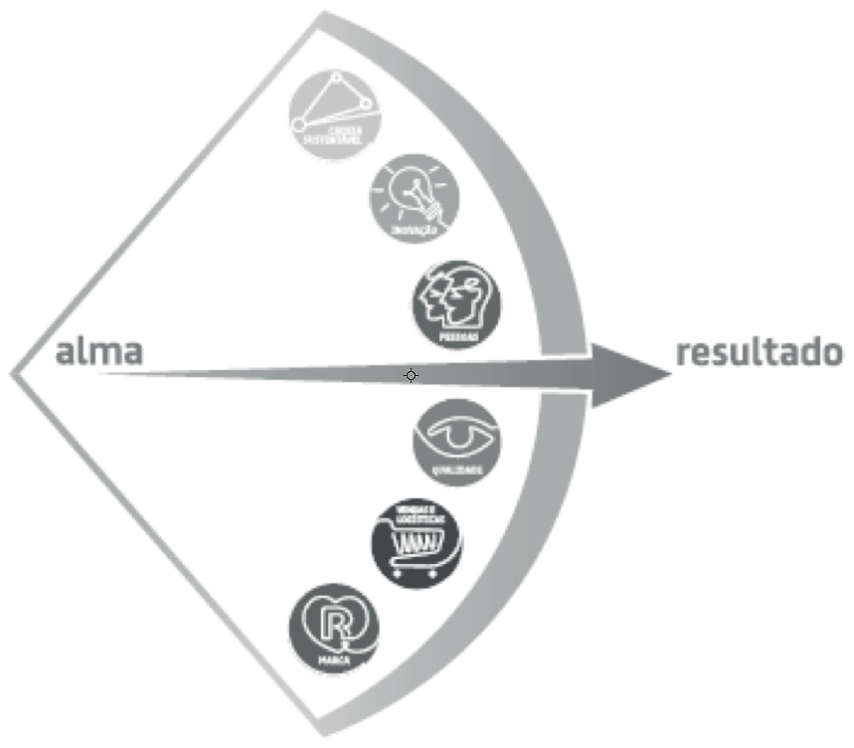

Fonte: Relato Integrado BRF (2015, p. 39). 
Assim sendo, o tema estratégia parece propício ao uso da metáfora visual, pois é preciso sinalizar o futuro para despertar o interesse de investidores e demais partes relacionadas, com linguagem clara, concisa e atrativa, parâmetros com grande apelo na linguagem visual. As estratégias divulgadas hoje são os compromissos de amanhã ao evidenciar as metas de longo prazo, as ações, os benefícios e o nível alcançado por meio do desempenho, tema do próximo tópico.

\section{Desempenho}

O RI deve informar o nível em que a organização alcançou os objetivos estratégicos para o período e quais os impactos sobre os capitais. Logo, o desempenho vai além do resultado financeiro, adentra na sustentabilidade, na governança e na estratégia (INTERNATIONAL INTEGRATED REPORTING COUNCIL, 2013).

Esta pesquisa identificou o desempenho como o tema que ocupa o maior número de páginas nos relatos analisados, dada à variedade de indicadores financeiros e não financeiros reportados nos relatórios específicos. Assim, a integração das métricas constitui um dos maiores desafios do Relato Integrado, em virtude da diversidade de premissas. Acerca do tipo de ícone, prevaleceu o uso de imagens, 313 páginas, nos 18 relatos.

A Figura 10 apresenta uma imagem metafórica como alternativa ao gráfico de barras convencional. Devido a isso, potencializa o significado do interpretante imediato. Seguindo a lógica de Peirce (2003), poderemos considerar o diagrama, por ter similaridade com as relações no desempenho entre os produtos, como signo indicativo, com origem em legi-signos, convenções (relações dos gráficos de barras), que se materializam por meio da iconicidade da imagem metafórica. No processo de interpretação, a tendência será o leitor fazer o caminho inverso: reconhecer, por meio da semelhança, as imagens das árvores (hipoícone imagético), organizadas como um gráfico de barras (hipoícone diagramático), que indicam outra coisa (função metafórica), o desempenho entre produtos. Chama a atenção nessa Figura as diferentes formas de uso e relações dos diferentes tipos de signos, que pode caracterizar uma importante estratégia de comunicação no RI. 
Figura 10 - Desempenho Operacional

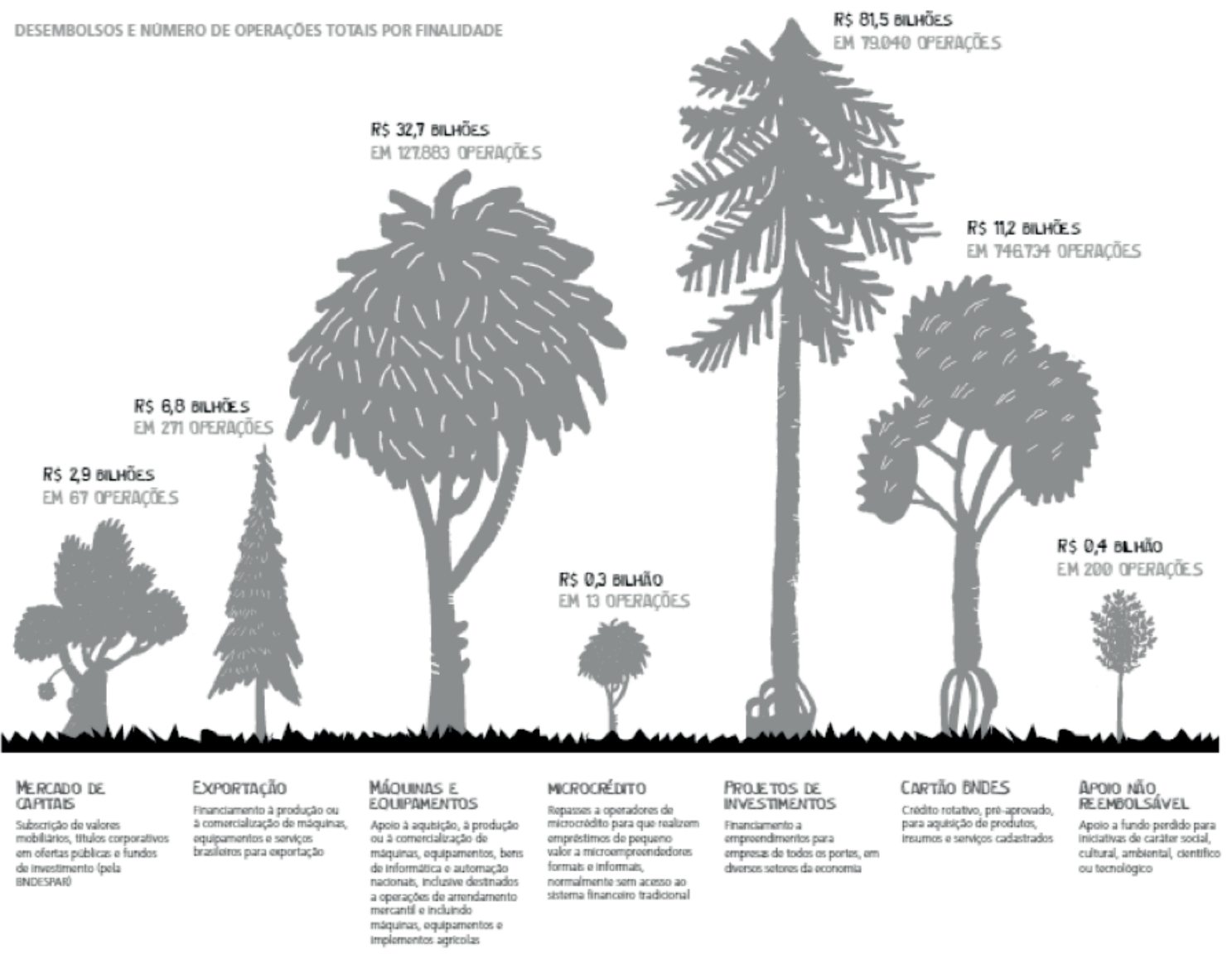

Fonte: Relato Integrado BNDES (2015, p. 18).

\section{Perspectivas}

Em consonância às orientações do IIRC (2013), o RI deve informar quais desafios e incertezas a organização tende a enfrentar para implantar sua estratégia e potenciais implicações para o modelo de negócios e desempenho futuro da empresa.

No que diz respeito ao tipo ícone presente nessa linguagem visual, sobressai o uso de imagens, seguidos mais adiante por diagramas. As metáforas visuais estão presentes em quantidade pouco representativa, que justifique seu exame. 


\section{Considerações Finais}

Ainda que se considere o predomínio dos signos indiciais nos relatos, que visam apontar para dados e informações existentes, as análises mostram que a forma de uso da metáfora visual merece uma atenção especial por parte dos elaboradores desse tipo de documento. Ao estabelecer o paralelismo entre o caráter representativo de um signo e algo diverso dele, as relações estabelecidas entre tais signos tende a atrair a atenção do observador e simplificar o potencial interpretativo.

Apesar de menos utilizada que a imagem e o diagrama, a metáfora foi identificada, principalmente, na evidenciação dos temas Estratégia e Desempenho. Algumas permeiam o relato inteiro, como as imagens de cordel no RI do BNDES/2015 (Figura 1), e outras são vinculadas a conteúdo específico, como o arco de prioridades da BRF (Figura 8), que evidencia o ponto de partida, as prioridades e o alvo (o resultado). A imagem metafórica também evidencia o desempenho como indicadores sociais, como nas Figuras 7 e 8 ao explorar as relações que se estabelecem entre os signos imagéticos, as mãos sobrepostas e 0 livro como telhado de uma casa.

Pouco comum é o uso da metáfora visual na evidenciação do desempenho econômico-financeiro, talvez pela formalidade comum na forma de exposição dessas informações nos relatórios originais, por seguirem orientações de órgãos reguladores. Assim como na categoria "Perspectiva", aparentemente, sem motivo.

O uso da metáfora visual no RI se mostra como um recurso inovador e eficiente à medida que permite a comunicação das informações financeiras ou não financeiras, em ambiente geralmente baseado na linguagem formal, em um documento que deve ser conciso e necessita integrar vários campos de conhecimento na gestão de negócios. O cuidado que se deve ter no processo de definição dos signos visuais é cuidar para que não haja o comprometimento do conteúdo, ao mesmo tempo em que possa potencializar o interpretante com base na completude e na concisão da informação por meio da linguagem visual.

\section{Referências}

CHENG, B.; IOANNOU I.; SERAFEIM G. Corporate social responsibility and access to finance. Strategic Management Journal, v. 35, n.1, p. 1-23, 2014. Disponível em: https:/onlinelibrary.wiley.com/doi/ abs/10.1002/smj.2131. Acesso em: 24 jun. 2016.

CONSELHO FEDERAL DE CONTABILIDADE. Resolução CFC nº 1.374, de 08 de dezembro de 2011. Disponível em: http://www.semesp.org.br/portal/pdfs/juridico2011/Resolucoes/res_CFC_1374(08_12).pdf. Acesso em: 4 abr. 2016.

ECCLES, R. G.; KRZUS, M. P. Relatório único: divulgação integrada para uma estratégia sustentável. São Paulo: Saint Paul Editora, 2011.

ECCLES, R. G.; SPIESSHOFER, B. Integrated reporting for a re-imagined capitalism. Harvard Business School General Management Unit. Working Paper No. 16-032, 2015. Disponível em: http://papers.ssrn. com/sol3/papers.cfm?abstract_id=2665737. Acesso em: 15 fev. 2016. 
FERRAZ JR., E. O conceito peirceano de metáfora e suas interpretações: limites do verbocentrismo. Estudos Semióticos, v. 7, n. 2, nov. 2011. São Paulo: USP, 2011. Disponível em: https://www.revistas.usp.br/esse/ article/view/35252. Acesso em: 5 set. 2018.

FREEMAN, R. E. Strategic management: a stakeholder approach. Cambridge University Press, 2010. Disponível em: https://scholar.google.com.br/scholar?hl=pt-BR\&q=Strategic+Management\%3A+a+stakehol der+approach\&btnG=\&lr=. Acesso em: 18 ago. 2015.

GLOBAL REPORTING INITIATIVE. Manual de implementação das diretrizes G4. 2. ed. Amsterdan, 2013. Disponível em: https://www.globalreporting.org/resourcelibrary/Brazilian-Portuguese-G4-Part-Two. pdf. Acesso em: 28 abr. 2016.

INTERNATIONAL INTEGRATED REPORTING COUNCIL. Framework integrated reporting, 2013. Disponível em: http://integratedreporting.org/wp-content/uploads/2014/04/13-12-08-THEINTERNATIONAL-IR-FRAMEWORK-Portugese-final-1.pdf. Acesso em: 13 abr. 2014.

MACIEL, P. A.; CINTRA, Y. C. De único a integrado: a história recente da evolução dos relatórios corporativos. In: CENTRE FOR SOCIAL AND ENVIRONMENTAL ACCOUNTING RESEARCH 2015. Salvador: UFBA, 2015. Disponível em: http://csearsouthamerica.net/events/files/conferences/1/schedConfs/4/ papers/176/public/176-682-1-PB.pdf. Acesso em: 9 maio 2016.

NÖTH, W. A teoria da comunicação de Charles S. Peirce e os equívocos de Ciro Marcondes Filho. Galáxia, n. 25, p. 10-23, 2013. Disponível em: http://www.redalyc.org/html/3996/399641251003/. Acesso em: 28 ago. 2017.

NÖTH, W.; SANTAELLA, L. Imagem: cognição, semiótica, mídia. São Paulo: Iluminuras, 2014.

NVIVO. Qualitative data analysis software. QSR International Pty Ltd. Version 11.3.2.779 for Windows, 2017.

PEIRCE, C. S. Semiótica. São Paulo: Perspectiva, 2003. (Coleção Estudos).

PESQUEUX, Y.; DAMAK-Ayadi, S. Stakeholder Theory in Perspective. Corporate Governance. Bradford, v. 5, n. 2, 2005.

ROCHA, T.; GOLDSCHMIDT, A. Gestão dos stakeholders: como gerenciar o relacionamento e a comunicação entre a empresa. São Paulo: Atlas, 2010.

ROTH, H. P. Is integrated reporting in the future? The CPA Journal, v. 84, n. 3, p. 62, 2014. Disponível em: https://scholar.google.com.br/scholar?hl=pt-BR\&q=Is+Integrated+Reporting+in+the+Future\%3F\&btnG=\& $\mathrm{lr}=$. Acesso em: 5 maio 2016.

SANTAELLA, L. Semiótica aplicada. São Paulo: Thomson, 2002.

\section{João Batista Freitas Cardoso}

Doutor em Comunicação e Semiótica pela Pontifícia Universidade Católica de São Paulo (PUC-SP), com Pós-Doutorado pela Escola de Comunicações e Artes da Universidade de São Paulo (ECA/ USP). Docente no Mestrado Profissional em Inovação na Comunicação de Interesse Público da Universidade Municipal de São Caetano do Sul (PPGCOM/USCS) e no curso de Publicidade e Propaganda da Universidade Presbiteriana Mackenzie (UPM). E-mail: jbfcardoso@uol.com.br. 


\section{Nadson Jaime Ferreira Alves}

Doutor em Administração pela Universidade de São Caetano do Sul (2017). Mestre em Controladoria e Contabilidade pela Universidade de São Paulo (1998). Graduado em Ciências Contábeis pela Universidade Federal do Pará (1990). Professor Associado I da Universidade Federal do Pará. Experiência na área de educação em ciências contábeis e análise das demonstrações contábeis. Pesquisa sobre: relato integrado; informação e tomada de decisão, linguagem visual, metodologias de ensino e aprendizagem, projeto político-pedagógico, empreendedorismo. Tese: Linguagem visual da informação financeira no Relato Integrado. E-mail: nadson@ufpa.br.

\section{Isabel Cristina dos Santos}

Administradora, Mestre em Administração (PUC-SP, 1999), Doutora em Engenharia (EPUSP, 2004), com Pós-Doutorado em Economia da Inovação (ITA, São José dos Campos, 2010). Atua desde 1999 no Ensino Superior, e desde 2005 atua como pesquisadora em estudos pós-graduados. Docente permanente do Programa de Pós-graduação em Administração da Universidade Municipal de São Caetano do Sul, dedica-se aos estudos sobre Gestão do Conhecimento, Inovação e Desenvolvimento Regional. Lidera o Grupo de Pesquisa em Sistemas e Redes de Inovação em áreas estratégicas. E-mail: isa.santos.sjc@gmail.com.

Recebido em: 25.09.2018

Aprovado em: 28.05.2019

Este artigo é publicado em acesso aberto (Open Access) sob a licença Creative Commons Attribution Non-Commercial (CC-BY-NC), que permite uso, distribuição e reprodução em qualquer meio, sem restrições, desde que sem fins comerciais e que o trabalho original seja corretamente citado. 